[Thornton, K. (2003). Teacher Refresher Courses and Effective Professional Development for Teachers. New Zealand Annual Review of Education, 12, 75-94]

\section{Teacher Refresher Courses and Effective Professional Development for Teachers}

\section{KATE THORNTON}

\section{Abstract:}

This report analyses the effectiveness of the Government's policies on professional development for teachers, with a particular focus on teacher refresher courses. The literature reveals that while professional development models based in schools and centres are the preferred method of creating change, a balance of professional development models is desirable. Professional development opportunities should meet the needs of teachers, their schools or centres as well as government priorities. Teachers should be involved in the design of their own professional development, and the needs of tangata whenua are an important consideration. Current government policy allows for a diverse range of professional development opportunities, but needs to be more specific in ensuring that teachers participate in these, including both school/centrebased and individual models such as teacher refresher courses, which have some unique features and benefits for teachers.

$\mathrm{T}$

he New Zealand Government, through the Ministry of Education, aims to improve the quality of the education system and raise the educational achievement levels of all students (Ministry of Education, 2001). In order to achieve this goal, there needs to be effective teaching and therefore ongoing teacher professional development. This review will examine the relevant literature, exploring both the importance of ongoing professional development and the models of delivery that best meet the needs of teachers and the schools and centres in which they work. The New Zealand Government policies on professional development for teachers will be detailed, different forms of professional development supported by these policies

\section{Kate Thornton}

considered, and their effectiveness discussed and analysed in the light of relevant literature. There will be a specific focus on the teacher refresher course model.

\section{Defining Professional Development}

Professional development is a broad term covering all activities through which teachers learn. Day (1999) gives an inclusive definition:

Professional development consists of all natural learning experiences and those conscious and planned activities which are intended to be of direct or indirect benefit to the individual group or school and which contribute through these, to the quality of education in the classroom. (p. 4)

Professional development includes activities that develop individual teacher's skills, knowledge and expertise, including formal in-service education courses defined as "identifiable learning activities in which practising teachers participate" (Organisation for Economic Cooperation and Development (OECD), 1998, p. 18). Different models of professional development will be discussed in a later section of this review.

\section{The Importance of Teacher Professional Development}

The link between professional development and teacher effectiveness, and the subsequent benefits for students' learning, are emphasised in much of the literature. The Education Review Office (2000) states that evaluation evidence gathered through reviews in New Zealand schools illustrates the link between effective in-service training and enhanced teacher performance. The OECD report Staying Ahead: Inservice Training and Teacher Professional Development (1998) links professional development for teachers to improved educational outcomes for students, and emphasises the importance of ongoing training and professional development to the teaching profession. Day (1999) states that "teachers are the school's greatest asset" (p. 2) and stresses the need for ongoing professional development, adding, "support for their wellbeing and professional development is, therefore, an integral and essential part of efforts to raise standards of teaching, learning and achievement" (p. 2). Cardno (1996) supports this view, suggesting that investment in professional development is essential both to the growth and revitalisation of the individual and the organisation, and is the most significant investment a school can make. 
Professional development may be even more important to presentday teachers than it has been in the past. The OECD report (1998) states that pre-service training alone is not sufficient preparation for teachers, particularly in a rapidly changing environment. It suggests that economic globalisation, social and educational changes and the introduction of new technology make teacher development even more of a priority now than in the past. The Education Review Office (2000) points out that the current age distribution of New Zealand teachers implies that many teachers did their pre-service training before the major curriculum and administrative reforms of the 1990s, and before the growth of information and communication technologies - hence the necessity for ongoing professional development.

\section{Government Policies on Professional Development}

The Government has also recognised the importance of teacher professional development. The Briefing for the Incoming Minister (Ministry of Education, 2002a), states"effective and focused professional development is essential to raise capability across all education sectors" (p. 19), and "ongoing, high quality professional development is the most effective way to raise achievement and reduce disparity in schools" (p. 27). Current government policies on professional development are contained in a variety of regulations and guidelines. These include the National Administrative Guidelines (NAGs) which require schools to have a strategic plan documenting policies, plans and programmes for professional development (NAG 2, Ministry of Education, 1999b), and to develop and implement personnel and industrial policies which promote high levels of staff performance (NAG 3, Ministry of Education, $1999 \mathrm{~b}$ ). The equivalent guidelines for early childhood centres are the Desirable Objectives and Practices (DOPs), which stipulate personnel policies promoting quality practices such as professional development for educators and management (DOP 11 (a), Ministry of Education, 1998a).

Teacher registration requirements, which apply to registered teachers in all sectors, also specify ongoing professional development. Of the four dimensions of teaching required for satisfactory teachers, two (professional relationships and professional leadership) mention professional development. Professional relationships, the criterion relating to the teacher's cooperative role with colleagues and families/whanau, requires teachers to develop professionally, and the professional leadership dimension requires teachers to encourage others and participate in professional development (Teacher Registration Board, 1997).

Professional standards for primary and secondary teachers were established to achieve consistency in performance management and to formalise government's expectations of professional performance. The professional standards for primary schools require teachers to "encourage others and participate in professional development" (Ministry of Education, 1998b, p. 21), while the standards for secondary teachers specify professional development under the headings of individual, collaborative and Treaty of Waitangi. There is an expectation that teachers will both "attend professional development programmes and other professional development activities" and "contribute to the professional development needs/activities of the department" (Ministry of Education, 1999c, p. 35)

A proportion of the funding for professional development is given directly to schools and centres through operations grants and bulk funds. This was estimated at $\$ 20$ million for schools in 1999. The Government funds the greater proportion of professional development centrally through contracts with providers, including the Teacher Refresher Course Committee (TRCC). In 1999 this amounted to over $\$ 69$ million, with the TRCC receiving $\$ 454,000$ (Ministry of Education, 1999a).

\section{Professional Development Available to New Zealand Teachers}

There is a broad range of professional development opportunities available to teachers in New Zealand schools and early childhood centres. A survey carried out by the Education Review Office as part of its study into effective in-service training in the school sector identified 17 different providers (Education Review Office, 2000). The most commonly used providers were Ministry of Education contracted providers, School Support Services, and trainers contracted by individual schools. Early childhood centres similarly access Ministryfunded professional development contracts from a variety of providers, 18 of whom currently hold contracts with the Ministry of Education (Ministry of Education, 2000).

Professional development in schools and early childhood centres takes a variety of forms. The focus may either be individual, such as formal study, attendance at seminars, conferences or in-service courses (e.g., teacher refresher courses held out of the school or centre), or group, where a teaching team works on an aspect of their practice 
together. As noted above, both individual and collaborative forms of professional development are stipulated in the professional standards for secondary teachers, though other policies, particularly those for early childhood teachers, are less clear on the forms professional development should take.

\section{Teacher refresher courses}

Teacher refresher courses are one model of professional development available to all New Zealand teachers. The Teacher Refresher Course Committee was established by Dr C. E. Beeby, Director General of Education, in 1945. Initially the committee was under the auspices of the Department of Education. Then, when the Ministry of Education was formed, the committee became an incorporated society entering into a contract with the Ministry of Education to deliver in-service courses for teachers. The committee comprises members of the teacher unions, hence the motto "for teachers by teachers" (Ministry of Education, 2002c, p. 4). The reason for establishing the committee was so that teachers could share some of the responsibility for their own professional development. This still occurs, as the contract between the TRCC and the Ministry states that courses need to meet both national priority and teacher-identified needs through "refresher in-service training courses" (p. 4).

Teacher refresher courses generally run for four to five days. They are residential courses, held mainly in the larger metropolitan centres because of cheaper travel costs and larger venues. Free travel for participating teachers is a significant feature. Schools and centres are required to pay course fees to cover accommodation and meals, though these costs are sometimes met by individual teachers. Funding from the Ministry of Education pays for course participants' travel costs, the course venue, presenters' fees and expenses and the costs of the course committee. The TRCC is required to provide 3340 participant days for national professional development each year. A minimum of 11 courses need to be provided, at least two of which will be planned for and by Maori (p. 6).

\section{Characteristics of Effective Professional Development}

There are a number of issues to be considered when determining the characteristics of effective professional development relevant to New Zealand teachers. These include models of delivery, consideration of individual and school/centre needs as well as government directions, the involvement of teachers in the design of their own professional development, and meeting the needs of tangata whenua.

\section{Models of delivery}

In-service courses such as teacher refresher courses have traditionally been the preferred method of professional development. However, in recent years there has been a shift to school/centre-based models. Here, teachers work together on an identified area with the focus on collaborative rather than individual learning.

Craft (2000) identifies the following weaknesses in the course-led model of professional development: that courses are aimed at individuals rather than groups of teachers, are not related to school needs, have limited impact on practice with little or no follow up, and are open to possible conflict between participants who are practising teachers and presenters who are theorists. The whole school/centre model is supported by the characteristics of effective professional development identified by Elmore and Burney (cited in Fullan \& Mascall, 2000). These characteristics include a focus on classroom applications, provision of opportunities for observation, critique and reflection and for collaboration and group support. Theissen (1992) supports classroom-based teacher development that

... focuses on student and teacher learning; gives control to teachers in concert with key stakeholders; is situated within the cultural realities of the classroom; consciously combines personal, educational and social reference points, and pursues significant changes in classroom practices through considered and collaborative actions. (p. 101)

The Working Party on the Length of the School Day and the School Year (1999) also recommends a school and classroom model, the rationale being that this places the responsibility for improvement in the hands of teachers and schools rather than the government. The Working Party suggests that successful development will occur through teachers working and planning together with support from outside experts. The involvement of outside advisors such as school support services or early childhood advisors helps negate some of the concerns regarding in-school or centre development, which, "conducted in isolation, is in danger of becoming introspective, and replicating weaknesses that already exist in the school as an organisation" (OECD, 1998, p. 41). Aspland, Elliot and MacPherson (1997) recommend that 
effective professional development opportunities incorporate elements of confrontation and challenge as well as support and reflection. This may be more likely to happen with outside input.

A possible weakness of the whole school/centre model is the lack of choice for individual teachers, resulting in professional development being seen more as an obligation than an opportunity (OECD, 1998). This view is supported by Baker and Lorrigan (2000) whose research into the most effective site for professional development showed that in some school-based programmes, the teachers' learning was negatively affected by their management's choices and expectations. Positive aspects of off-site courses have been identified. These include allowing teachers the opportunity to meet and exchange ideas with people from different backgrounds and to gain new perspectives. It is suggested that off-site courses may provide new theoretical understandings and new approaches (OECD, 1998). Fullan \& Hargreaves (1996) believe the value of courses can be underestimated. One of the benefits they see is the opportunity for personal reflection away from the school environment.

There seems to be agreement in the literature that different models all have something to offer and may complement each other - "no one model of in-service development is adequate to meet all training needs" (OECD, 1998, p. 41). The Green Paper reviewing teacher education described both school-based professional development and courses, conferences and workshops as being effective (Ministry of Education, 1997). The report also emphasised the need for teachers to work collaboratively on improving teacher practice.

Some characteristics of effective professional development apply whatever the model of delivery. These include identification of needs prior to, and evaluation and follow up after, the professional development (Craft, 2000), as well as consideration of the principles of adult learning. Willis (2000) identifies several key issues to consider with regard to professional development and adult learning. These are the need to ensure that relevant theory is provided in order to underpin practice, that professional learning has relevance to and ownership by teachers, and that learning should be situated in the teachers' real world, should challenge them to examine their beliefs about teaching and learning and have an impact on educational change. Conners (1991) reinforces these views, in stating that professional development programmes must pay more attention to teachers as adult learners and individuals if they are to be effective.
Balancing individual professional development objectives with school/centre-wide objectives and government directions

An important characteristic of effective professional development is that it addresses individual, school/centre-wide and national priorities and needs (ERO, 2000). Cardno (1996) emphasises the importance of a balanced approach to professional development. She believes that areas that need to be addressed include curriculum, personal, management and school development. This holistic view is supported in the OECD report (1998), which promotes professional development aimed both at updating content knowledge needed to deliver the curriculum effectively, and developing individual skills, attitudes and approaches.

Clement and Vandenberghe (2000) describe a tension between collegiality and autonomy in the professional development of teachers. While supporting a collegial approach to professional development, they warn that this should not happen at the expense of teachers' individuality. This view is supported by Aspland, Elliot and MacPherson (1997), who suggest that effective professional development recognises both the collaborative and individual nature of teaching. Among the recommendations in the World Bank report on Teacher supply, training and professional development (Craig, Kraft, \& Du Plessis, 1998) is that in-service programmes should focus on areas specific to teachers' needs and that there be ongoing guidance, support and sharing between teachers. It is also important that professional development be "sustained, ongoing and intensive, supported by modelling, coaching and collective problem solving around specific problems of practice" (OECD, 1998, p. 54).

The need for professional development to reflect the needs of all stakeholders is emphasised by Day (1999), who makes the point that successful school development is dependent on successful teacher development and that planning and supporting professional development is the joint responsibility of teachers, schools and governments. The fact that the ideal situation is not always realised is made in the OECD report: "Ideally, in-service training and professional development should form a collaborative effort from start to finish, involving all the stakeholders in the process - the reality falls far short of that" (OECD, 1998, p. 31). 


\section{Involving teachers in the design of their professional development} opportunities

Strategies for professional development can been described as either top-down, directed by government policies and emphases (e.g., literacy and numeracy), or bottom-up, driven by the needs of the schools, centres or individuals. Fullan and Hargreaves (1996) warn against top-down approaches that underestimate teachers' knowledge, experience and learning needs. They promote professional development models that take into account the context in which teachers work and the teaching culture, alongside the teacher as a person with individual values and purposes. Day (1999) agrees that teachers' professional development needs vary according to their personal and professional history and current circumstances. This view is summarised in Figure 1.

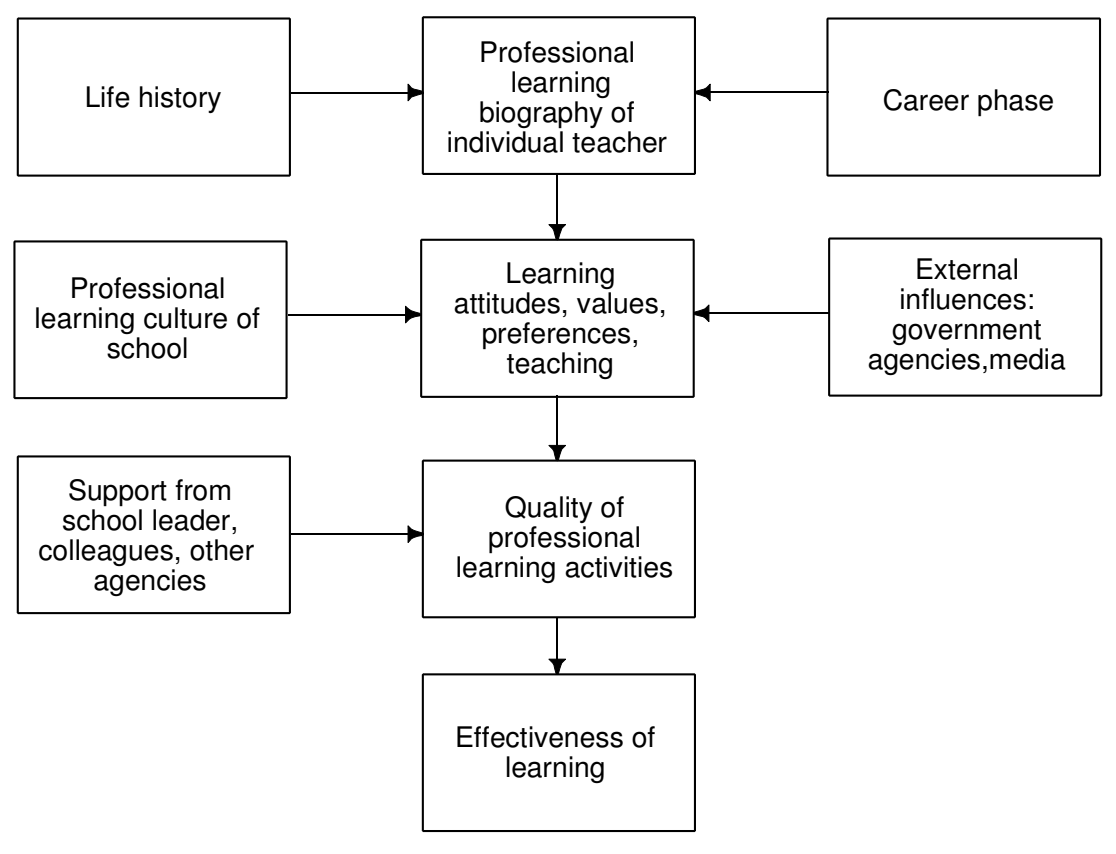

Figure 1 Factors contributing to the quality of professional learning (Day, 1999, p. 4)
The importance of focusing on the individual is also emphasised by Hargreaves and Fullan (1992) who argue that teacher development involves "understanding not only the knowledge and skills that teachers should acquire but also understanding what sort of person the teacher is and the context in which most teachers work" (p. 16). Several writers comment on teachers' need to access different types of professional development at different stages of their career (Aspland, Elliot \& MacPherson, 1997; Catron \& Groves, 1999; Conners, 1991; Hargreaves \& Fullan, 1992). The implications of this view are that the needs of teachers within a school or centre cannot be totally met by the same professional development programme.

Aspland, Elliot and MacPherson (1997) promote a move from a top-down policy-oriented model of professional development to one that is "teacher-centred, dynamic and interactive, embedded in the professional practice of teachers, and oriented to the active construction of professional knowledge within the broader contextual realities" (p. 3). Clark (1992) proposes that individual teachers be given responsibility for their own professional development for two reasons; firstly because the learning is more likely to be valued when they have some control of the process; and secondly, because each teacher is unique and no centrally designed process can meet the needs of a wide range of teachers.

The concept of the teacher as researcher is promoted in much of the literature (Day, 1999; Education Review Office, 2000; Ginns, Heirdsfield, Atweh \& Watters, 2001; Goodson, 1992; Robertson, 1994). Action research involves a teacher or group of teachers identifying an aspect of their work for investigation in order to "improve their practices, their understanding of these practices, and the situations in which they work" (Carr \& Kemmis, cited in Goodson, 1992, p. 113). Teacher research, particularly action research, is seen as a very effective way of linking improvement and enquiry to classroom practice (Fullan \& Hargreaves, 1996). Action research can be undertaken by individual teachers but is also useful in enhancing collaborative learning and peer support. The importance of the professional learning community is emphasised by Fullan and Mascall, "if a teacher does not work in a professionallearning community, where teachers work collaboratively, sharing passion and purpose for their work, then professional development is short-lived" (2000, p. 34). 


\section{Meeting the needs of tangata whenua}

Several government policy initiatives focus on professional development to meet the needs of Maori (tangata whenua). These include professional development for Maori medium teachers, enhancing mainstream teachers' responsiveness to Maori, as well as initiatives to develop leadership and management of Maori principals and principals in Maori medium schools (Ministry of Education Group Maori, 2002, p. 23). Alongside these initiatives sits the requirement for all secondary teachers to participate in professional development that includes opportunities relating to the Treaty of Waitangi, and to expand their knowledge in current issues and initiatives in education including Maori education (Ministry of Education, 1999c, p. 27). There are no specific requirements relating to the professional development needs of Maori laid down for primary and early childhood teachers at present.

Tangata whenua needs will become even more significant with the proportion of Maori students in the population expected to double over the next twenty years. There has also been a significant increase in the number of Maori graduating as teachers, from 304 in 1995 to 625 in the year 2000 (Ministry of Education Group Maori, 2002, p. 64). The needs of this group of teachers will have to be addressed through government policy.

\section{Evaluation of Teacher Refresher Courses As Effective Forms of}

\section{Professional Development}

In this section of the report, teacher refresher courses will be analysed according to the four main issues regarding effective professional development previously discussed. According to the literature reviewed, courses are not the preferred model of delivery. There is agreement however, that effective professional development needs to take a variety of forms and meet a variety of needs, and course attendance is one option to be used in conjunction with school/centre based models. "The ideal is to combine such on-site development with a sufficient amount of externalised learning to enable teachers to reinforce practical experiences with theoretical understanding" (OECD, 1998, p. 43). An advantage of the course format is that it allows for teachers to move out of their school/centre and to be exposed to new ideas and ways of thinking, by hearing and working with nationally and sometimes internationally recognised experts. Networking with others in their field from around the country is beneficial, particularly for those who may be in isolated positions because of specialist subject areas or school/centre size.

Wylie (1999) reports that teachers wish to have more professional development from their colleagues in other schools than they actually get. She also notes that rural teachers receive less advice and support from their colleagues than their urban counterparts. These needs can be met through teacher refresher courses. Some issues seem particularly well-suited to the teacher refresher course format. These include courses that may be relevant only to one or a few teachers in a school or centre - such as leadership and management courses, or courses for alternative education providers or teachers of specialist subjects where networking is particularly valuable.

In terms of the importance of professional development meeting the needs of all stakeholders, teacher refresher courses comply well. There is wide consultation by the TRCC on topics for courses. The groups consulted include teacher unions, Colleges of Education, School Support Services, Ministry of Education, Education Review Office and the New Zealand Qualifications Authority. Individual teachers are also consulted, through being invited on evaluation forms to make suggestions for future courses. Individuals and schools/centres choose whether to attend the courses, based on the course statement sent out. This should clearly articulate the aims of the course and allow teachers to decide whether it will meet their needs. It needs to be emphasised that the course statement must accurately reflect the course programme, as the participants do not receive the programme until they have confirmed their attendance. Within courses there is generally a range of workshops to attend, so participants have some choice to allow for different experiences, interests and needs. Teachers are extensively involved in the design of Teacher Refresher Courses. The committee is made up of teachers from the four sectors, and the course directors and committee members are, as far as possible, practising teachers.

The areas highlighted through the literature review that are not so well addressed in this model include the provision for teachers to be able to design a programme that meets their individual needs. Greater attention might be given to allowing teachers attending a course to identify their own learning goals, and identify how these could be met through a flexible programme.

A key requirement of effective professional development is that there is a link between the professional development programme and the individual teacher's practice. The connection between the learning 
within teacher refresher courses and subsequent changes in practice in the classroom or centre needs to be addressed. Professional development forms that encourage teachers to set goals and look at how they will implement these back in their workplaces have been developed. A sample of one in six teachers is surveyed six weeks after attending a course, to find out how useful the course has been and what effect it has had on their student's learning. At present the information gathered is not used by TRCC. However, even the process of engaging the teacher in reflection may be of value. A course of professional study needs to combine practice and reflection on it (Craft, 2000). This view emphasises the importance of building reflection time into courses, something that is recommended in the information for course directors, but does not always happen.

The needs of tangata whenua appear to be well provided for through teacher refresher courses. An analysis of 30 recent courses offered by the TRCC, between 1998 and 2001, shows that 17 percent of course participants identified as Maori. This compares with statistics showing Maori making up 9 percent of primary teachers and 7 percent of secondary teachers (Ministry of Education Group Maori, 2002, p. 11). As previously mentioned, there are opportunities for Maori to develop course structures and programmes autonomously to meet tangata whenua needs. It is required that "the Treaty of Waitangi is acknowledged, affirmed and implemented" in course structures, processes, and resources (Teacher Refresher Course Committee, 2001, p. 3). It has been acknowledged by the committee that this is not always easy for course directors and committees, and this issue was the focus for the TRCC's annual professional development day in 2002.

The advantages and disadvantages of teacher refresher courses may be summarised as follows:

Advantages:

- They are designed by teachers for teachers;

- They are national courses which allow for sharing of ideas and resources between teachers from different regions, and access to experts;

- Payment of travel costs means equitable access for all teachers;

- Maori teachers are able to determine their own needs and course content;
- Professional development needs of individual teachers are able to be met;

- Cross sector courses allow networking between early childhood, primary, secondary and tertiary teachers.

Disadvantages:

- They are often attended by only one teacher from a school or centre - hence teachers may not have collegial support for making changes once back in their centre/school;

- Follow-up learning opportunities are not regularly available;

- Courses are removed from the classroom/centre setting - hence no practical opportunities to implement changes occur until after the course.

Recommended changes to teacher refresher courses to improve their effectiveness are as follows:

1. That all course programmes provide opportunities for teachers to develop individual learning goals, to reflect on their current practices, any changes they wish to make when back in their school or centre, and how they will implement these changes.

2 That there be more opportunities to follow up participants after courses to support the consolidation of new learning into classroom/centre practice. This follow-up could either be regionally based face-to-face contact or via email networks.

\section{Analysis of the Effectiveness of Government Policy on Professional Development}

The Government invests a significant amount of money in teacher professional development. While this is of benefit to schools and centres - "The logic of investing in professional development is straightforward: there is no more effective way to undertake substantive change in schools" (Fullan \& Mascall, 2000, p. 35) - the government needs to ensure that the money is well spent. The present policy of professional development being funded partially by schools and centres through operating grants and bulk funding and partially through centrally funded contracts does seem to allow for the meeting the needs of all stakeholders - individuals, schools and centres as well as government interests. 
The OECD report (1998) points out that investment of financial resources needs to be "accompanied by the formulation of coherent, comprehensive and consistent policies" (p. 29). The investment is there, but the consistent, comprehensive and coherent policies seem to be lacking.

The Education Review Office comments that the regulatory requirements for teacher professional development are "relatively few", considering how important it is to the Crown (2000, p. 6). The requirements vary across sectors, with the professional standards for secondary teachers being the most prescriptive in specifying professional development to meet individual and school requirements, as well as relating to the Treaty of Waitangi. Access to and participation in professional development may vary widely from school to school and centre to centre because of the lack of specific guidelines. The requirements need to be made more explicit to ensure that professional development accessed by all teachers is effective in improving the learning outcomes for children in schools and centres. Areas to be addressed include ensuring teachers have access to a variety of professional development opportunities, both school/centre-based (where teachers work collaboratively on an agreed issue or area of practice), and individual, where specific personal needs can be met through course or conference attendance or study. There needs to be specific direction about the forms of professional development in which teachers should participate. School/centre-based development should form a regular part of the professional development of all teachers and this should be supplemented by other forms of professional development which allow for external stimulus and sharing of ideas. A clear policy document covering all aspects of professional development rather than a variety of unrelated guidelines and regulations would be of benefit to teachers and their schools or centres.

The Ministry of Education, in its recent curriculum update on literacy, acknowledges the need for professional development to be "relevant to and owned by teachers and focus on their everyday concerns" (2002b, p. 5). This acknowledgement needs to be reflected in government policy. Teachers need to be involved in the design of their own professional development, which needs to be personally relevant and to reflect the principles of adult learning. These requirements can be met by ensuring teacher input into professional development planning, having more specific requirements as described above, as well as more meaningful evaluation of current programmes. The OECD
(1998) sets out ten policy principles related to professional development. Many of these relate to meeting the needs of individual teachers and schools and have already been discussed. One that is relevant to government policy is the importance of systematic evaluation of the effectiveness of professional development on children's learning. Evaluation of professional development programmes needs to investigate whether significant change in teaching practices has occurred. At present there tends to be an emphasis on evaluating more easily measurable but less important indicators such as the presenter and venue (Craig, Kraft, \& Du Plessis, 1998). There needs to be more meaningful evaluation of the effectiveness of different forms of professional development on children's learning.

Specific professional development programmes have been implemented to cater for the needs of Maori teachers. These policy initiatives need to be broadened to ensure all teachers in New Zealand schools and early childhood centres receive professional development to assist them in addressing the needs of tangata whenua in recognition of the principles of the Treaty of Waitangi. With the increasing numbers of Maori children in our schools and centres and the disparities between their levels of achievement and those of non-Maori students, this is an area of great importance to the education sector.

The Education Review Office report (2000) commented on the need for a professional body for teachers and signalled the future establishment of the Teachers' Council. There appear to be tensions between the role of the Teachers' Council as an professional body for teachers and the fact that it is a Crown entity and is expected to serve education agencies and organisations, parents and the public as well as teachers (Teachers' Council, 2002). Sullivan warns that a professional body established by the Government will "create the opposite of what a professional body should be. The intention is to extend government control over teachers' conditions of service rather than to empower them as professionals" (1999, p. 152). Delays in establishing the Council and electing permanent teacher representatives mean that it is too early to assess its effectiveness as a professional body. There is an expectation from the Ministry of Education that the Teachers' Council will be involved in "disseminating what it understood to be good professional practice through teacher pre-service and in-service education" (Ministry of Education, 2002a, p. 6). However, there is at present no indication of how this will be done. 


\section{Conclusion}

If the New Zealand Government is to meet its goal of raising educational achievement, then ongoing professional development leading to effective classroom teaching is essential. The OECD report emphasises the importance of professional development policy-"Good teachers are good learners and the ultimate test of the success or failure of policies for in-service training and professional development of teachers will be their effect on learning outcomes for children" (OECD, 1998, p. 29). Professional development policies must provide sufficient resources and guidance to ensure that teachers are involved in the design of, and have access to, a variety of professional development opportunities. The needs of the different stakeholders must be met, as well as the increasingly important needs of tangata whenua.

Current Government policy funds and allows for a range of professional development opportunities, but I would argue that it is not specific enough about what forms professional development should take. Clearer requirements for primary and early childhood teachers in particular should be developed, in consultation with these sectors, to give guidance on participation in effective professional development. Teacher refresher courses provide one model of professional development which is meeting the needs of teachers, and should continue to be funded along with a range of other school/centre-based models. There also needs to be more effective evaluation of government-funded professional development and its ultimate effects on children's learning. Finally, the role of the Teachers' Council in supporting and promoting ongoing professional development needs to be considered and clarified.

\section{References}

Aspland, T., Elliot, B., \& MacPherson, I. (1997). Empowerment through professional development. set: Research Information for Teachers, 1, $1-4$.

Baker, F., \& Lorrigan, G. (2000). Where it's at: Professional development courses: School-based or campus-based? New Zealand Journal of Educational Administration, 5, 16-22.

Cardno, C. (1996). Professional development: An holistic approach. New Zealand Journal of Educational Administration, 11, 25-28.

Catron, C., \& Groves, M. (1999). Teacher to director: A developmental journey. Early Childhood Education Journal, 26(3), 183-188.
Clark, C. (1992). Teachers as designers in self-directed professional development. In A. Hargreaves \& M. Fullan (Eds.), Understanding teacher development (pp. 75-84). New York: Teachers College Press.

Clement, M. \& Vandenberghe, R. (2000). Teachers' professional development: A solitary or collegial adventure? Teaching and Teacher Education, 16, pp. 81-99.

Connors, B. (1991). Teacher development and the teacher. In P. Hughes (Ed.), Teachers' professional development (pp. 53-81). Hawthorn, Victoria: Australian Council for Educational Research.

Craft, A. (2000). Continuing professional development. London: Routledge Falmer Press.

Craig, H., Kraft. R., \& Du Plessis, J. (1998). Teacher development: Making an impact. Washington DC: USAID/World Bank.

Day, C. (1999). Developing teachers: The challenges of lifelong learning. London: Falmer Press.

Education Review Office. (2000). In-service training for teachers in New Zealand schools. Wellington: Education Review Office.

Fullan, M., \& Hargreaves, A. (1996). What's worth fighting for in your school. New York: Teachers College Press.

Fullan, M., \& Mascall, B. (2000). Human resources in education: A literature review. Prepared for the New Zealand Ministry of Education. $<$ www.minedu.govt.nz $>$

Ginns, I., Heirdsfield, A., Atweh, B., \& Watters, J. (2001). Beginning teachers becoming professional through action research. Educational Action Research, 9(1), pp. 111-133.

Goodson, I. (1992). Sponsoring the teacher's voice: Teachers' lives and teacher development. In A. Hargreaves \& M. Fullan (Eds.), Understanding teacher development (pp. 110-121). New York: Teachers College Press.

Hargreaves, A., \& Fullan, M. (1992). Understanding teacher development. New York: Teachers College Press.

Ministry of Education. (1997). Quality teachers for quality learning: A review of teacher education (Green paper). Wellington: Ministry of Education.

Ministry of Education. (1998a). Quality in action/Te Mahi Whai Hua. Wellington: Learning Media. 
Ministry of Education. (1998b). Teacher performance management. <www.minedu.govt.nz>

Ministry of Education. (1999a). Briefing for the incoming Minister of Education. <www.minedu.govt.nz>

Ministry of Education. (1999b). National education guidelines. <www.minedu.govt.nz>

Ministry of Education. (1999c). Professional standards: Criteria for quality teaching. Wellington: Ministry of Education.

Ministry of Education. (2000). Pitopito Korero. Wellington: Ministry of Education.

Ministry of Education. (2001). Annual report 2000-2001. $<$ www.minedu.govt.nz>

Ministry of Education Group Maori. (2002). Nga Haeta Matauranga: Annual report on Maori education 2000/2001 and direction for 2002. Wellington: Ministry of Education.

Ministry of Education. (2002a). Briefing for the incoming Minister of Education. <www.minedu.govt.nz>

Ministry of Education. (2002b). Curriculum update: He korero matauranga. Issue 50. Wellington: Ministry of Education.

Ministry of Education. (2002c). Variation to the agreement of services between the TRCC and the Ministry of Education. Wellington: Ministry of Education.

New Zealand Teachers Council. (2002). <www.teacherscouncil.org.nz/01/01a.htm>

Organisation for Economic Cooperation and Development. (1998). Staying ahead: In-service training and teacher professional development. Paris: OECD.

Robertson, J. (1994). The development of an education theory of leadership and research as praxis. New Zealand Journal of Educational Administration, 9, 13-21.

Sullivan, K. (1999). Teacher standards and professionalism: Contested perspectives in a decade of reform. New Zealand Journal of Educational Studies, Special Issue: A decade of reform in New Zealand: Where to now? 34(1), 144-155.

Teacher Refresher Course Committee. (2001). Information for course directors and planning committees. Wellington: Teacher Refresher Course Committee.
Teacher Registration Board. (1997). Information for newly registered teachers. Wellington: Teacher Registration Board.

Thiessen, D. (1992). Classroom-based teacher development. In A. Hargreaves \& M. Fullan (Eds.), Understanding teacher development (pp. 85-109). New York: Teachers College Press.

Willis, D. (2000). Adult learning and the professional development of teachers. Wellington: Victoria University of Wellington.

Working Party on the Length of the School Day and the School Year. (1999). Towards the learning culture-celebrating diversity, opportunity, excellence: A review of the length of the school day and the school year. Wellington: Ministry of Education.

Wylie, C. (1999). Ten years on: How schools view educational reform. Wellington: New Zealand Council for Educational Research.

\section{The author}

Kate Thornton currently works as an early childhood adviser and lecturer at the Wellington College of Education. Her educational background includes secondary teaching and extensive involvement in the Playcentre movement. Kate is currently completing her MEd at Victoria University of Wellington. Her research interests are leadership and professional development, and she has been a member of TRCC since 2000 . 